\title{
Balur and Improving Quality of Life
}

Gatra Ervi Jayanti*, Saraswati Subagjo

Research Institute of Free Radicals, Malang, Indonesia

\section{ABSTRACT}

Balur treatment aimed to leach free radicals overwhelmingly produced in unhealthy body with rubbed over the human body. In Balur used some amino acid, bawang sabrang (Eleutherine palmifolia (L.) Merr), kopi balur (Mixed Coffea arabica L. with Acetosal), coconut Water (Cocos nucifera L.), secang (Caesalpinia sappan L.) and "Divine" smoke from cloves (Syzygium aromaticum (L.) Merr. \& L. M. Perry) and tobacco (Nicotiana tabacum L). This is an observation research of balur application in volunteers during four years at Rumah Sehat, Malang, Indonesia. The result suggested that balur can improve quality of life in male volunteers i.e. $61.54 \%$ cancer (39 volunteers); $80 \%$ tumor (20 volunteers); $86.36 \%$ diabetes mellitus (22 volunteers); $93.33 \%$ heart (15 volunteers); 92.86\% autism (28 volunteers); $72.73 \%$ hepatitis (11 volunteers); $100 \%$ neuron disease (2 volunteers); $93.62 \%$ various of disease ( 94 volunteers). in female volunteers: $72.31 \%$ cancer (65 volunteers); $88.57 \%$ tumor (35 volunteers); $75 \%$ diabetes mellitus (16 volunteers); 100\% hemorrhoid ( 3 volunteers); $100 \%$ stroke (3 volunteers); $40 \%$ cardiomegaly (5 volunteers); $66.67 \%$ autism (3 volunteers); $88 \%$ various of disease (50 volunteers) and 100\% healthy (3 volunteers).

Keywords: Balur, herb in Balur process, improving quality of life

\section{INTRODUCTION}

Balur is the improving method of Javanese traditional medical treatment for better life quality. Balur used some free radicals scavenging natural products and aromatic organic chemical components such as amino acid and other aromatic organic components. The body is undergone Balur treatment is laying down on the grounded copper plate. The natural products used are bawang sabrang (Eleutherine palmifolia (L.) Merr), kopi balur (Mixed Coffea arabica L. with Acetosal), coconut water (Cocos nucifera L.), secang (Caesalpinia sappan L.) as well as "Divine" smoke from cloves (Syzygium aromaticum (L.) Merr. \& L. M. Perry) and tobacco (Nicotiana tabacum L).

Balur is considered enable to pull out free radicals and heavy metals such as mercury from the human body and will persist in the waste [1]. This hypothesis is supported by series of observations $[2,3]$ of the repeating number of balur treatments, which showed the more patterned electrical current between the copper plate into the ground state. Balur is improving

\section{*Corresponding author:}

Gatra Ervi Jayanti

Research Institute of Free Radicals, Malang, Indonesia

E-mail: gervij@yahoo.com method from kerikan, pilisan or baluran with cuka aren and bawang.

\section{MATERIALS AND METHODS}

This is an observation research to record the effect of balur application on medical improvement of volunteers. This research conducted in Research Institute of Free Radicals, Malang, East Java, Indonesia, during four years (2009-2012). Volunteers who began the study were men and woman, age range of volunteer from baby (18 months) until 83 years. Volunteers have a variety of disease, from light case until severe. Most of volunteers have cancer. Generally, before balur, volunteers has done the treatment in various places, they have used a pharmaceutical drugs and chemo.

This research method, the data were collected from volunteers by following: (1) Personal identification, (2) Medical record of their health problem, (3) The doctor observation and the laboratory test. The balur treatment was done for tree days continue, one time each day, then followed by medical doctor observation. In severe case of volunteers, the balur was applied everyday for seven days. Afterward, the balur continuous was applied for once a week for one month, once for every two weeks at the next second month, and then once a month within a year. 
Volunteers who have balur how many times grouped into number of balur. Group 1 if volunteers have 1-5 times balur, group 2 for 6-10 times balur, group 3 for 11-20 times balur, group 4 for 20 times consecutive and group 5 for 20 times treatment.

The data of life quality were collected and analyzed, at the day after balur. The data obtained then transformed into three categories of life quality that are 1 : No improvement, 2: Gain better life quality, and 3: Better life quality supported by improving medical records.

\section{RESULTS AND DISCUSSION}

Volunteers with better life quality have higher percentage than no improving life quality (Table 1 and 2). Better life quality if the quality of healthcare improves, reduced pain, even no pain at all, and supported by improving medical records. Whereas no improving life quality if volunteers were not recovery from disease.

Table 1. Percentage of improving life quality in male volunteers after balur

\begin{tabular}{llll}
\hline \multirow{2}{*}{ No } & Disease and Number of & \multicolumn{2}{c}{ Percentage (\%) } \\
& \multicolumn{1}{c}{ Volunteers } & Better life & No improving \\
& & quality & life quality \\
\hline 1 & Cancer (39) & 61.54 & 38.46 \\
2 & Tumor (20) & 80 & 20 \\
3 & Diabetes mellitus (22) & 86.36 & 13.64 \\
4 & Heart (15) & 93.33 & 6.67 \\
5 & Autism (28) & 92.86 & 7.14 \\
6 & Hepatitis (11) & 72.73 & 27.27 \\
7 & Neuron Disease (2) & 100 & - \\
8 & Various of Disease (94) & 93.62 & 6.38 \\
\hline
\end{tabular}

Tabel 2. Percentage of improving life quality in female volun-

\begin{tabular}{llcc}
\multicolumn{3}{c}{ teers after balur } \\
No & Disease and Number of & \multicolumn{2}{c}{ Percentage (\%) } \\
& \multicolumn{1}{c}{ Volunteers } & $\begin{array}{c}\text { Better life } \\
\text { quality }\end{array}$ & $\begin{array}{c}\text { No improving } \\
\text { life quality }\end{array}$ \\
\hline 1. & Cancer (65) & 72.31 & 27.69 \\
2. & Tumor (35) & 88.57 & 11.43 \\
3. & Diabetes mellitus (16) & 75 & 25 \\
4. & Hemorrhoid (3) & 100 & - \\
5. & Stroke (3) & 100 & - \\
6. & Cardiomegaly (5) & 40 & 60 \\
7. & Autism (3) & 66.67 & 33.33 \\
8. & Various of disease (50) & 88 & 12 \\
\hline
\end{tabular}

No improving life quality indicated by charts in blue, there are not changes in the quality of life after balur. Better life quality or improving life quality indicated by red color. Green color indicates a good quality of life and better. Volunteers have recovery from their disease (Figure $1-11$ ).

Cancer case (Figure 1 and 2), better life quality occurred in every group of balur treatment. The failure of treatment with limited increasing life quality occurred usually happened on volunteers who came to the institute with very bad prognosis and very poor life quality.

Our data, in general, also indicate that the volunteers who had got better life quality after treatment, and feeling better tend to stop came to the institute do to some unknown reason. The volunteers who attttended balur up to more than 20 times predominate by volunteer's cancer problem.

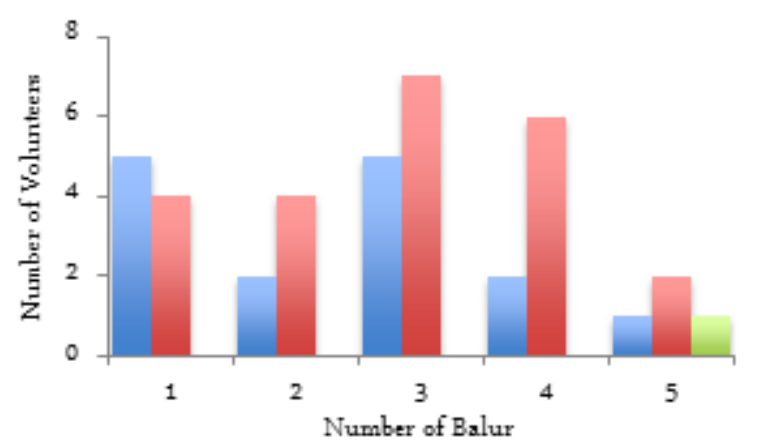

Figure 1. Cancer in male volunteers after Balur. Blue color: no improving life quality; Red color: better life quality; Green color: good and better life quality

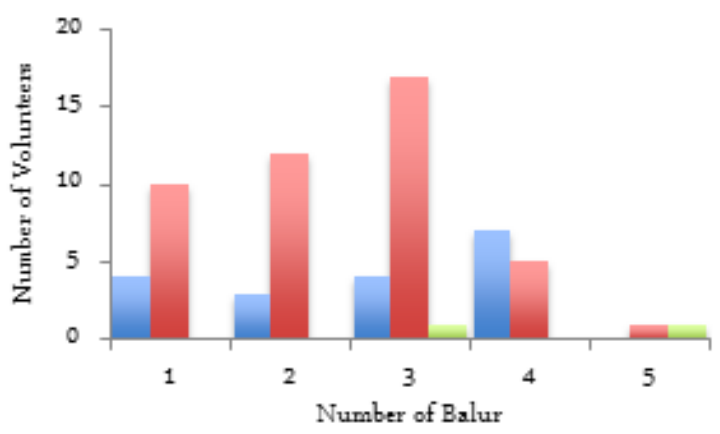

Figure 2. Cancer in female volunteers after Balur. Blue color: no improving life quality; Red color: better life quality; Green color: good and better life quality

Volunteers with tumor, much improvement, start from group 1. Female volunteers (Figure 4), no improving life quality lower than male volunteers (Figure 3 ). Usually the volunteers who had got better life quality after treatment, and feeling better tend to stop came to the institute do to some unknown reason. 


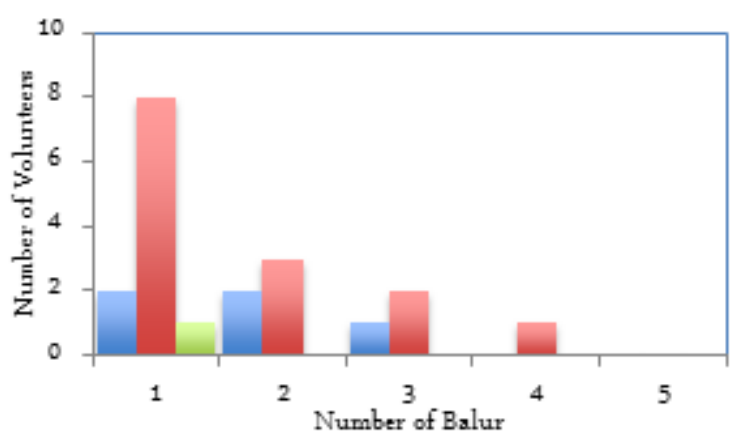

Figure 3. Tumor in male volunteers after Balur. Blue color: no improving life quality; Red color: better life quality; Green color: good and better life quality

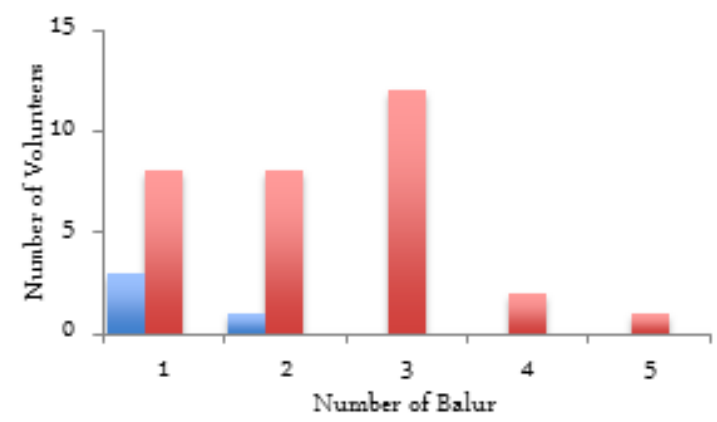

Figure 4. Tumor in female volunteers after Balur. Blue color: no improving life quality; Red color: better life quality

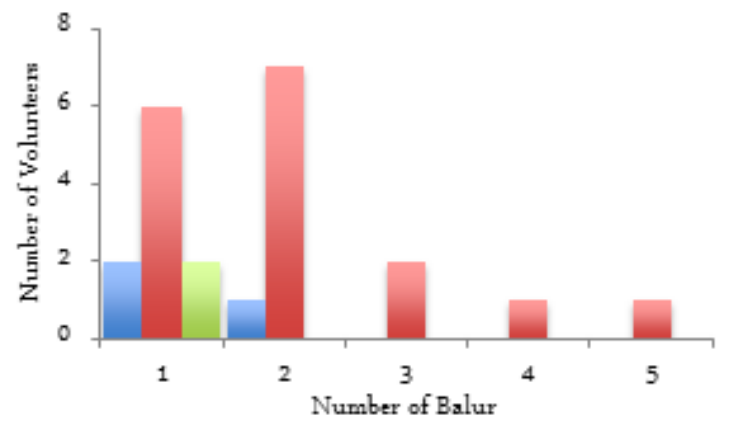

Figure 5. Diabetes Mellitus in male volunteers after Balur. Blue color: no improving life quality; Red color: better life quality; Green color: good and better life quality

Balur in diabetes mellitus case quite successful, it can be shown better life quality in Figure 5 and 6. Failure rate in female with diabetes mellitus higher than male volunteers.

Heart case only occur in male volunteers (Figure 7), improving life quality is high and start from group 1. While number of volunteers with no improving life quality only slightly.

Volunteers with autism occur in children, Figure 8 show significant result, rate failure is lower. Usually the volunteers a slight improvement of life, average they are not continue the balur. Although there are volunte-

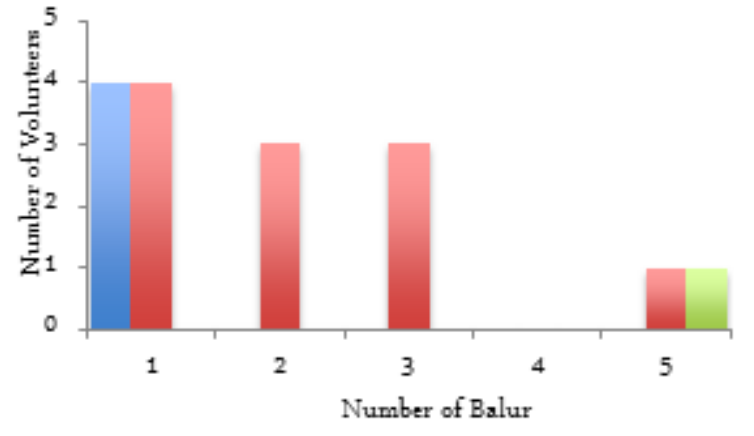

Figure 6. Diabetes mellitus in female volunteers after Balur. Blue colour: no improving life quality; Red colour: better life quality; Green colour: good and better life quality

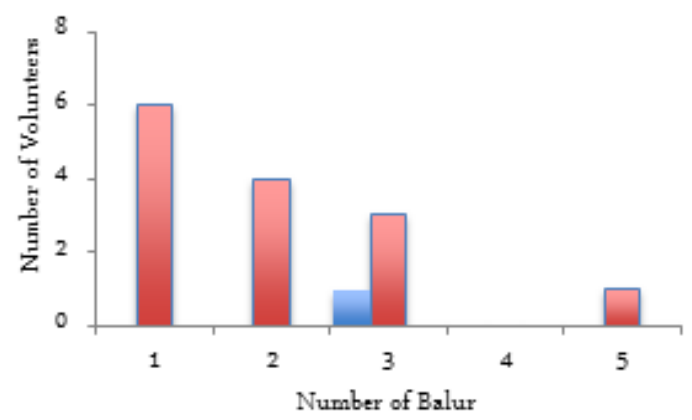

Figure 7.Heart in male volunteers after Balur. Blue color: no improving life quality; Red color: better life quality

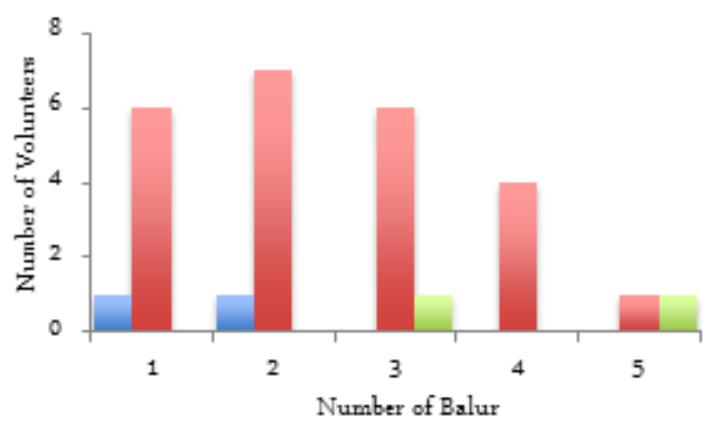

Figure 8. Autism in male volunteers after Balur. Blue color: no improving life quality; Red color: better life quality; Green color: good and better life quality

ers with better life quality. Autism in female only three volunteers and two volunteers show better life quality (not show in chart).

Volunteer with hepatitis only in male, Figure 9 show better life quality with highest number of volunteers is group 1. While the failure rate appear in two groups (1 and 3 ).

Neuron disease, in this case cerebral palsy only two male volunteers and they are better life quality. Better life quality also occurs in Hemorrhoid and stroke female volunteers (not show in chart). 


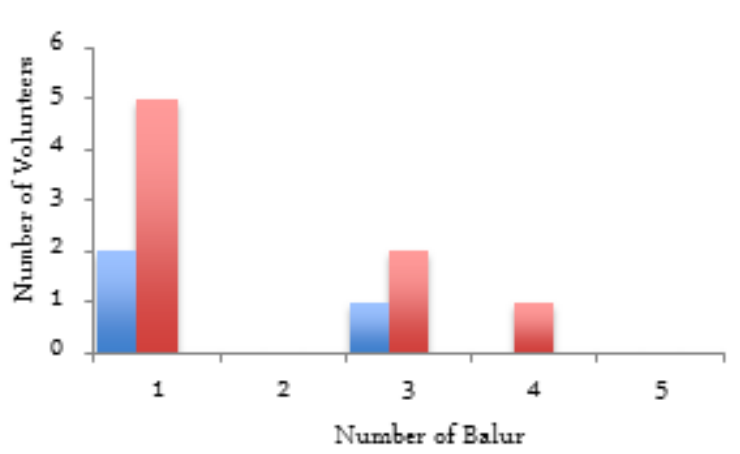

Figure 9. Hepatitis in male volunteers after balur. Blue color: no improving life quality; red color: better life quality

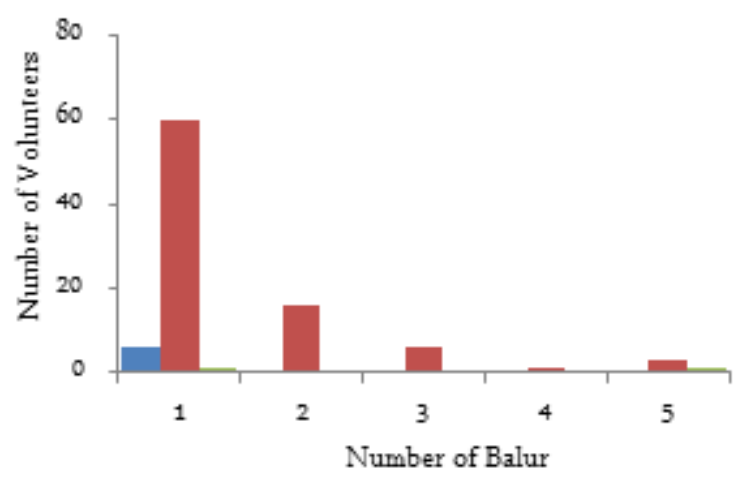

Figure 10. Various of disease in male volunteers after Balur. Blue color: no improving life quality; Red color: betttter life quality; Green color: good and better life qual ity

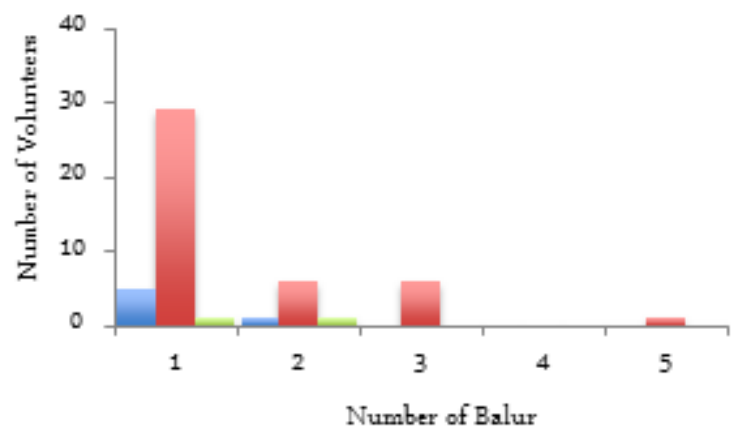

Figure 11. Various of disease in female volunteers. Blue color: no improving life quality; Red color: better life quality; Green color: good and better life quality

Male (Figure 10) and female volunteers (Figure 11) with various of disease show better life quality in group 1 , because simple case and lower rate failure.

Amino acid uses in balur process are scavenger. When balur materials rubbed in human body, free radicals pulled out through skin and trapped by aluminium foil and electric current in balur waste left in copper plate flow in the earth. Free radicals from un- healthy volunteers can decline and improving life quality.

Acetosal and aromatic amino acids together with some aromatic hydrocarbon may scavenge mercury radicals in the living body. These aromatic compounds should be in the form of biradicals before then can be used their magnetic forces to trap gaseous $\mathrm{Hg}$ radicals. The $\mathrm{Hg}^{*}+$ radicals trapped in the paramagnetic field of biradicals by means of applying series of scavengers rubbed on whole surface of the body [4].

Empirically bawang dayak/sabrang have used local society as medicine for some kind disease like breast cancer, lowering for high blood pressure (hypertension), diabetes mellitus, lowering for cholesterol, boil, intestine cancer and stroke preventing [5]. Bawang dayak bulbus extract contain flavonoid and many biradical aromatic compound with antioxidant function, inhibit fat peroxidase. This antioxidant activity is mostly due to their hydroxylated phenolic group presence in molecule structure and the grasp through free radicals against and activities as metal chelate [6].

Coconut water (coconut liquid endosperm), with its many applications, is one of the world's most versatile natural products. This refreshing beverage is consumed worldwide as it is nutritious and beneficial for health. There is increasing scientific evidence that supports the role of coconut water in health and medicinal applications. Micronutrients (nutrients needed in small quantities) such as inorganic ions and vitamins in coconut water play a vital role in aiding the human body antioxidant system. Hyper metabolism gives rise to an increased production of reactive oxygen species (or free radicals), as a result of increased oxidative metabolism. Such increase in free radicals will cause oxidative damage to the various components of the human cell, especially the polyunsaturated fatty acids in the cell membrane, or to the nucleic acids in the nucleus. Fortunately, living organisms have well developed antioxidant systems to neutralize the most detrimental effects of these oxidizing species. Micronutrients have important functions in this aspect. For example, they act directly to quench free radicals by donating electrons, or indirectly as a part of metallo enzymes (a diverse class of enzymes that require a catalytic metal ion for their biological activity) such as glutathione peroxidase (selenium) or superoxide dismutase (zinc, copper) to catalyst the removal of oxidizing species [7].

Cloves are aromatic herb that has many useful purposes. The aroma of the clove is pleasant yet spicy and can be used to make drawers and closets smell nice. Cloves has some medicinal purposes as well and it 
tastes good in certain dishes like spice cake. Cloves like to grow in hot tropical climates like the islands of Indonesia. Cloves are a very useful herb that has many uses for the body and the aroma. Cloves, many medicinal uses have been most famously applied to toothache, and for mouth and throat inflammation. Clove cigarettes, also called kreteks, generally contain $60 \%$ to $80 \%$ tobacco and $20 \%$ to $40 \%$ ground clove. Eugenol, one of the chemicals in clove, acts like menthol to reduce the harshness of tobacco smoke [8].

In past, tobacco used for medicine. This is evident from the statement as follows. In history tobacco used for health, in 1529 a Spanish missionary priest Bernadito de Sahagun, collected information that breathing the odor of fresh green leaves of tobacco relieved persistent headaches. Green or powdered tobacco leave for colds catarrh should be rubbed around inside the mouth. In Mexico before 1519, medical user of tobacco as antidiarrheal, narcotic and emollient. Tobacco leave used relief of pain, used in powdered form for relief of catarrh and applied locally to health wounds and burns. The nineteenth century, tobacco smokes per rectum for condition as varied as strychnine poisoning, constipation, hemorrhoid bleeding, strangulated hernia, tetanus, hydrophobia and worms. Tobacco administered externally: bites of poisonous reptiles and insects; hysteria; pain; neuralgia; laryngeal spasm; gout; growth of hair; tetanus; ring-worm; rodent ulcers; ulcers; wounds; respiratory stimulant. Tobacco administered by mouth: strangulated hernia (smoke by mouth); malaria or intermittent fever; dislodging obstructive material from esophagus by inducing vomiting. Tobacco by inhalation: Nasal polyps. New methods of tobacco treatments included aetherial tincture, poultices, snuff patches [9].

The various species of Nicotiana contain many other alkaloids. Leaves and juice used for skin disorders, possibly including basal cell cancer, might tobacco leaves contain an anticancer agent. Excess dosage of tobacco will do harm, Charlton suggest should set aside the prejudices generated by the ill effects of tobacco smoking and examine the leaves systematically for substances of therapeutic value [9].

Element or liquid nicotine-gold $(\mathrm{Au})$ nano particle in tobacco not contaminated $\mathrm{Hg}^{*}$ particle, because tobacco environment for grow still relatively clean. Than as medicine, tobacco used as natural antibiotic before being discovered penicillin antibiotic. Like other plants, tobacco performs photosynthesis mechanism. Tobacco contained higly stable $\mathrm{C}, \mathrm{H}, \mathrm{N}$ and $\mathrm{O}$ atoms, structured and non-toxic. Them are aromatic compount which would be excessive energy when contaminated $\mathrm{Hg}^{*}$ metal $-\mathrm{Hg}^{*}$ covering nicotin-gold $(\mathrm{Au})$, chlorophyll, other aromatic hydrocarbon compounds (HC) from phenatren (tar). $\mathrm{Hg}^{*}$ prefer to be in tobacco compared with other plants because tobacco have nicotingold $(\mathrm{Au})$ and a number of polycyclic aromatic hydrocarbon compounds (HC) are sensitizer. Thousand of compount element of $\mathrm{C}, \mathrm{H}, \mathrm{N}$ and $\mathrm{O}$ in tobacco consists of polycyclic aromatic hydrocarbon compounds, nitrosamine family, phenolic groups, diBenzo $(\mathrm{a}, \mathrm{h})-\mathrm{X}$ family and others, and nicotin-gold (aurum). Between that aromatic compount there are nonsensitizer and sensitizer. That conditions that causes tobacco and cigarette be toxic and can not longer be used for treatment. That encourages and is basic innovation of healthy cigarette, Divine Cigarette. Principle of Divine Cigarette is catching $-\mathrm{Hg}^{*}$ metal in tobacco (cigarette) with scavenger with is a combination formula of aromatic amino acid compound and EDTA in tridestilation water solution. Eliminate free radicals, especially mercury element $(\mathrm{Hg})$ and other heavy metals in kretek cigarette that strategies used in making cigarette smoke be safe. After free radicals can be tamed in smoke, the existence of particles that are polymer composite organic components be useful for healthy body [10].

Theoretical thought of Zahar and Sumitro [10] then used as a research idea by Sadhana [11]. Sadhana using Sprague-Dawley rat exposed to filter cigarette smoke (control) and filter "Divine" cigarette smoke (treatment). Filter "Divine" cigarette smoke is a filter cigarette smoke containing "Divine" solution (acetosal, some amino acid and distilled water). "Divine" solution as free radical scavenger in filter cigarette smoke, then pulls out of the body have the shape of sweat and urine. Sadhana research results showed that filter " $\mathrm{Di}$ vine" smoke cigarette influence to the diameter of alveolus. Alveolus diameters of filter "Divine" have smaller size than the filter smoke cigarette exposure. The study proves the existence of damage and additions the diameter of the lung, and potential improvement due to "Divine" treatment in the smoke cigarette.

Zahar and Sutiman's theory also used for some research idea [12,3,13]. Albab [12] used BALB/c mice and exposure with filter "Divine" cigarette smoke (filter types: B, DE, DF). There are differences in the post-exposure to filter "Divine" cigarette smoke. Three types of filters "Divine" capable of triggering an innate and adaptive immune system modulator. Cytokine secretion in vitro tests showed that exposure does not alter the "Divine character of lymphocytes in response to 
antigen. However, lymphocytes T CD4+ and T CD8+ in the treatment of $\mathrm{B}$ and DF filters tend to express IFN- $\gamma$. DE Filters have in common with ordinary filter, expressed TNF- $\alpha$. Smoke transformation with "Divine" cause modified the character and nature of their interactions. This produces a different modulation profiles with the character of the smoke initially.

Grounding current in balur process is also studied. Grounding current due to an electron mobility of the ground to the table copper. Waste from balur process containing free radicals with the electric charge $(+)$. First balur obtained Igrounding range are 0.118-0.802 $\mu \mathrm{A}$, third balur 0.160-0.94 $\mu \mathrm{A}$ and fifth balur 0.112$0.946 \mu \mathrm{A}$ [3]. Conductivity value ranges from balur waste are 10-11 $1 / \Omega . c m$ until 10-9 $1 / \Omega . \mathrm{cm}$. The conductivity values indicate properties of semiconductor materials [14].

\section{CONCLUSIONS}

Balur process use some amino acid and herb. Balur improving quality of life and make patient recovery from their disease. Usually the volunteers who had got better life quality after treatment, and feeling better tend to stop came to the institute do to some unknown reason.

\section{ACKNOWLEDGMENT}

Authors thank to Professor Sutiman Bambang Sumitro, M.Sc., D.Sc., for the reviewing.

\section{REFERENCES}

1. Zahar G (2012) The Balur and Divine Kretek Therapy (The philosophy and basic ideas). http:// smartbio. org/ research/the-balur-and-divine-kretek-therapy-thephilosophy-and-basic-ideas/.

2. Ratnanindia DYR (2008) Studi komposisi limbah hasil proses terapi pembaluran dengan analisa puncak spektrum inframerah. Skripsi. Universitas Brawijaya, Fakultas Matematika dan Ilmu Pengetahuan Alam.
3. Wulansari PP (2009) Suatu studi kasus pengaruh nilai konduktivitas limbah terhadap arus grounding pada proses terapi balur. Skripsi. Universitas Brawijaya, Fakultas Matematika dan Ilmu Pengetahuan Alam.

4. Sumitro SB (2012) Study on biradical based complex structure: A possible way to find out natural nanoparticles from the human body. www. smartbio.org.

5. Faraline L (2011) Bawang dayak (Eleutherine palmifolia) sebagai tanaman obat multifungsi, Bawang Dayak (Eleutherine palmifolia) sebagai Tanaman Obat Multifungsi. http://www.jamu.biologi.ub.ac.id/

6. Nurliani A, Santoso HB, Rusmiati (2012). Efek antioksidan ekstrak bulbus Bawang Dayak (Eleutherine palmifolia) pada gambaran histopatologis paru-paru tikus yang dipapar asap rokok. Biosciencetiae 9 (1): 60-69.

7. Yong JWH, Ge L, Ng YF, Tan SN. The chemical composition and biological properties of coconut (Cocos nucifera L.) Water. Rev. Molecules 14:5144-05164, 2009.

8. Bhowmik D, Sampath Kumar KP, Yadav A, Srivastava S, Paswan S, Dutta AS (2012) Recent trends in indian traditional herbs Syzygium aromaticum and its health benefits, Journal of Pharmacognosy and Phytochemistry 1(1):2278-4136.

9. Charlton A (2004) Medicinal uses of tobacco in history. JR Soc Med. 97(6): 292-296.

10. Zahar G, Sumitro SB (2011) Divine kretek rokok Sehat. Masyarakat Bangga Produk Indonesia. Jakarta.

11. Sadhana U (2015) The smoke effect of divine filtered cigarette in alveoli diameter and KI-67, BCL-2, tunel enzyme expressions of sprague-dawley. Dissertation. Medicine and Health Faculty. Diponegoro University. Semarang.

12. Albab FA (2012) Local and systemic immunomodulation following exposure of divine filtered kretek smoke on BALB/c mice. Master Thesis. Postgraduate Program. Brawijaya University.

13. Miza L (2009) Studi pengaruh komposisi dan konsentrasi logam utama pada limbah terhadap arus grounding pada terapi pembaluran. Skripsi. Universitas Brawijaya, Fakultas Matematika dan Ilmu Pengetahuan Alam. 